\title{
А.3. Искендерова
}

Гянджинский Государственный Университет, Азербайджан, г. Гянджа, e-mail: arifaiskander@mail.ru

\section{ФОРМИРОВАНИЕ НРАВСТВЕННО-ПСИХОАОГИЧЕСКИХ КАЧЕСТВ ЖЕНСКОЙ АИЧНОСТИ КАК ПРИОРИТЕТНАЯ ПРОБАЕМА В ТВОРЧЕСТВЕ АЗЕРБАЙАЖАНСКИХ ПРОСВЕТИТЕАЕЙ}

\begin{abstract}
Статья посвящена изучению образа женщины, ее нравственно-психологических качеств в трудах азербайджанских писателей. Объектом исследования были избраны произведения азербайджанских писателей-просветителей конца XIX - начала XX века. ПреАмет исслеАования приоритетные проблемы в творчестве этих писателей и место женского вопроса в их творчестве. Как известно, начиная с 60-70-ых годов XIX века, передовые ^юди Азербайджана, ведя борьбу за пробуждение своего народа, были абсолютно уверены в однозначной связи его просвещения, воспитания подрастающего поколения, обеспечения зАоровья, быта с проблемой женской свободы. Не случайно, что Аанный вопрос, будучи в начале XX века в одном ряду с Аругими важными вопросами социальной жизни народа, находился в центре борьбы противоположных Аруг другу сил - передовых и реакционных сил. Так, в редакции журналов «Фуюзат» и «Шаяа^а» собрались преАставители реакционной клерикальной идеологии. С ними объеАинились и мусульманские Ауховные лица. Генеральной минией их политики в отношении женщины было утверждение существования женщины в замкнутой и в изолированной от общества форме. Что касается прогрессивной части азербайджанской интемлигенции, то эти силы объединились вокруг журнала «Молма НасредАин» и его редактора Ажалила Мамедкулизаде. В ряды представителей передовой демократической культуры, призывающих всех ^юдей на борьбу за свободу женщин, за право на образование, на получение работы входили М.А. Сабир, Омер Фаиг, А. Ахвердиев, М.С. Ордубади, Али-гули Гамкюсар и др. Таким образом, проведенное исследование показало, что в творчестве азербайджанских просветителей не раз поднимались вопросы о роли и месте женщины в развитом обществе, гАе она должна занимать достойное положение.
\end{abstract}

Кмючевые слова: женская мичность, нравственность, социально-психологические качества, самосознание, образованность.

\author{
A.Z. Iskenderova \\ Ganja State University, Azerbaijan, Ganja, \\ e-mail: arifaiskander@mail.ru \\ Formation of moral and psychological qualities of woman's personality \\ as a priority problem in the works of Azerbaijani enlighteners
}

The article is devoted to the study of the problem of the formation of the moral and psychological qualities of the female personality. The object of the study was the works of Azerbaijani writersenlighteners of the late XIX - early XX century. The subject of the research is the priority problems in the work of these writers and the place of the women's issue in their work. As it known, starting from the 60s-70s of the XIX century, the progressive people of Azerbaijan, fighting for the awakening of their people, were absolutely sure of the unequivocal connection of its education, upbringing of the younger generation, ensuring the health of everyday life with the problem of women's freedom. It is no coincidence that this issue, being at the beginning of the twentieth century on a par with other important issues of the social life of the people, was at the center of the struggle of opposing forces - advanced and reactionary forces. Thus, representatives of the reactionary clerical ideology gathered in the editorial offices of the magazines Fuyuzat and Shalala. Muslim clerics also united with them. The general line of their policy towards women was to affirm the existence of women in a closed and isolated form from society. As for the progressive part of the Azerbaijani intelligentsia, these forces have united around the magazine "Molla Nasreddin" and its editor Jalil Mammadguluzade. The ranks of the representatives of the advanced democratic culture who took an irreconcilable position in relation to ideas, especially the actions of reactionary forces calling on all people to fight for women's freedom included M. A. Sabir, Omer Faig, A. Hakhverdiyev, M. S. Ordubadi, Ali-guli Gamkusar and etc. tion.

Key words: female personality, morality, social and psychological qualities, self-awareness, educa- 


\title{
А.З. Искендерова
}

Гянджи Мемлекеттік университеті, Әзірбайжан, Гянджа к.

*e-mail: arifaiskander@mail.ru

\section{Әзірбайжан ағартушылары шығармаларындағы басты мәселе - әйел тұлғасының адамгершікік-психологиялық қасиеттерін қалыптастыру}

\begin{abstract}
Мақала әйел тұлғасының адамгершілік-психологиялық сапасының қалыптасуы мәселелерін зерттеуге арналған. Зерттеу нысаны ретінде XIX ғасырдың аяғы мен XX ғасырдың басында өмір сүрген Әзірбайжан ағартушы-жазушыларының шығармалары алынған. Зерттеу пәні жазушы шығармаларындағы осы мәселенің басым тұстары мен олардың шығармашылығындағы әйел мәселелерінің орны. Белгілі болғандай, XIX ғасырдың 60-70-ші жылдарынан бастап Әзірбайжанның алдыңғы қатарлы азаматтары өз халқын ояту үшін күрес жүргізуде оның ағартушылығының, жас ұрпақты тәрбиелеудің, салауатты тұрмыспен қамтамасыз етудің әйел бостандығы мәселесімен бір мәнді байланысы барына сенімді болды. Бұл мәселе XX ғасырдың басында халықтың әлеуметтік өмірінің басқа да маңызды мәселелерімен тең болуымен қатар, бір-біріне қарама-қарсы алдыңғы қатарлы және реакциялық күштердің күресінің орталығында болғандығы кездейсоқ емес. Сонымен, "Фуюзат" және "Шалала" журналдарының редакциясында реакциялық діни идеологияның өкілдері жиналды. Олармен бірге мұсылман дінбасылары да бірікті. Олардың әйелдерге қатысты саясатының жалпы желісі әйелдердің қоғамнан жабық, және оқшауланған түрінде болатындығын растау болды. Әзірбайжан зиялыларының прогрессивті бөлігіне келетін болсақ, бұл күштер "Молма Насредлин" журналы мен оның редакторы Ажалил Мамедкулизале төңірегінде бірікті. Әсіресе реакциялық күштердің іс-әрекеттеріне қатысты шешіммейтін позицияны иеленген, әйелдер бостандығы үшін күреске шақырған алдыңғы қатарлы демократиялық мәдениеттің өкілдері қатарына М.А. Сабир, Омер Фаиг, А. Ахвердиев, М.С. Ордубади, Али-гули Гамкюсар және басқалар кірді.

Түйін сөздер: әйел тұлғасы, аАамгершілік, әлеуметтік-психологиялық, қасиеттер, өзін-өзі тану, білімдімік.
\end{abstract}

\section{Введение}

Женская проблема существовала во все эпохи, во всех общественных формациях. И даже до нашей эры, в период матриархата на женщин выпадала столь тяжелая обязанность, как обеспечение общины в материальном плане. Смена различных формаций, изменение религиозных взглядов и образа жизни породили новые проблемы для женщин. Хотя, различия в образе жизни, в мировоззрении между женщинами, живущими в мусульманском мире, и принадлежащими к другим религиям женщинами и существовали, у каждой были специфические сложности. И поэтому изучение существовавших на всех этапах человеческой жизни проблем женщин вне зависимости от расы, религиозной принадлежности, национальности всегда будет актуально (Farajev, 2011: 13).

Обладающая общественной значимостью в азербайджанской истории проблема женщин в нашей национальной литературе была поднята в разных темах (Bahkshaliev, 2011: 23). Если возьмем в качестве объекта анализа произведения наших писателей, поэтов и драматургов конца XIX - начала XX веков в этом аспекте, то увидим, что в этих произведениях говорится об осужденном положении, нахожде- нии под гнетом, бесправии азербайджанской женщины.

\section{Методы исследования}

Методологическую основу данной работы составили труды, изучающие женское мировосприятие и его художественную реализацию (Alizade, 2017), Азербайджанское просветительство (Abdullabekova, 2016), социальную психологию (Problemi, 2008) и нравственно-социальное становление личности (Maryenko, 1985).

Абдуррахим бек Ахвердиев, один из выдающихся представителей азербайджанской реалистической и демократической литературы, является одним из тех, кто связал свою литературно-общественную деятельность с народной массой. В своих трудах, написанных до советизации Азербайджана, писатель изобразил склонности народа к идеалам свободы и демократии, а в последующий период отобразил преимущества советской идеологии. Ахвердиева беспокоили социально-политические явления своей эпохи. Он фиксировал свои идеи об этих явлениях, высказывал к ним свое отношение (Hagverdiyev, 1941: 53). Находясь постоянно среди народа, Aхвердиев хорошо знал проблемы, с которыми он сталкивается. Он не мог оставаться равнодуш- 
ным к бесправию азербайджанских женщин. И вел борьбу с творцами этого бесправия. Его желание заключалось в достижении азербайджанской женщиной счастья, получении образования и обретения грамотности. А свое презрение к тем, кто отобрал у нее это право, демонстрировал в своих произведениях. В первые периоды своего творчества Ахвердиев, описывая положение, в котором оказались женщины, протестовал против подобного отношения общества к ним, в последующие годы он приветствовал борьбу женщин, воспевал новую ситуацию, вводимые в обществе нововведения, увязывал с претворяемой в жизнь успешной политикой. Данный второй период уже был советским периодом. И в это время в соответствии с новой идеологией отвергалось прежнее отношение к женщине. И эта картина полностью удовлетворяла Ахвердиева.

В творчестве всемирно известного азербайджанского композитора Узеира Гаджибекова, занимающего значимое место в качестве педагога, писателя, журналиста в истории нашей культуры, были интересные моменты. Это, прежде всего, его публицистические статьи. Он сыграл большую роль в появлении и развитии, издаваемых в начале XX века газет, как «Хайят» («Жизнь»), «Иршад» («Верный путь»), «Тарагги» («Прогресс»), «Ени игбал» («Новое будущее»). В этот период Узеир-бек был самым активным журналистом, корреспондентом, и даже некоторое время редактором газеты «Азербайджан», являвшейся органом Азербайджанской Демократической Республики. В написанных в эти годы статьях он приветствовал деятельность Азербайджанской Демократической Республики, и особенно проводимую ею политику образования. Особого внимания заслуживает его объективное отношение к национальному вопросу. Так, в частности, в одной из своих статей он писал следующее: «... таким образом, подробно продемонстрировав Европе все наши особенности, все достоинства, достойно должны доказать свое право на самостоятельную жизнь и самостоятельную организацию правительства, чтобы в будущем люди, которые будут представлять нашу страну на мирных конференциях, пройдя политико-правовой и национальный экзамен, вернувшись на Родину, имели на руках подтверждение независимости» (Hajibekov, 1985:145).

Одним из самых важных вопросов, нашедших глубокий анализ в художественных произведениях Наджаф-бека Везирова, является во- прос отношения к семье и женщине. Наджаф-бек Везиров с присущей ему точностью видел нравственный упадок, происходящий в буржуазных и помещичьих семьях (Vezirov, 1951: 34). Наблюдая за обществом, он видел, что люди вступают в брак не по любви, а по таким факторам, как грубый материальный расчет, торгашество и выгода... Он также видел, как буржуазные и помещичьи семьи превращаются в гнезда, распространяющие аморальность. Все эти деформации, касающиеся вопросов семьи и женщины, нашли отражение во всех его пьесах.

В центре внимания, продолжающего идеи Гасан-бека Зардаби, у М.Т. Сидги были вопросы семьи и нравственного воспитания. Он очень много писал о роли семьи в нравственном воспитании. По его мнению, семья определяет нравственный облик человека. Именно семья несет непосредственную ответственность за нравственные качества людей. По его мнению, рождение ребенка не требует от родителей большого героизма, ведь и животные способны продолжать род. Поэтому истинная заслуга родителей заключается именно в воспитании своих детей. Умственное и нравственное воспитание детей очень сильно зависит от уровня умственного развития матери (Sidgi, 1969: 72), поскольку в мусульманских семьях воспитанием детей занимаются преимущественно матери.

М.Т. Сидги неоднократно подчеркивал необходимость усовершенствования семейного воспитания детей. Говоря в целом о семье, о нравственности, он придерживался резких позиций в отношении к такому позорному явлению, как многоженство, которое он считал показателем «бедой нации», и призывал имеющих нескольких жен мужчин к самому резкому общественному порицанию.

В контексте сказанного, особо хочется выделить имя еще одного азербайджанского поэта - М.А. Сабира. В его произведениях проблема женской свободы была поднята и решена в широком психологическом плане и отражена с высокой художественной достоверностью. В качестве наглядного примера отношения поэта к данной проблеме можно проанализировать сатиру «Gavur q1z1» («Дочь неверного»). В этой работе автор, перечисляя все обязанности женщины перед мужем и детьми, все работы, что она должна выполнять по дому, заботы по воспитанию детей, в противовес всему этому напоминает, что её муж имеет право привести в дом новую, молодую жену: 
Sal başını aşağə sən, ancaqn işində ol,

Paltar yü, ev süpür, elə xidmət, gavur q1zı .

Yoxsa nə borcuna ki, ər övrət alar, alar

Övrətsən ancaq eylə itaət, gavur q1zı

Ordir, özü bilər, neçə övrət alar, alar

Heyvan kimi durar, baxar övrət gavur q1zı (Sabir, 1962: 23)

«Опусти голову вниз, занимайся лишь работой своей,

Стирай одежду, подметай в доме,

прислуживай, неверного дочь.

Какое дело твое, что муж жену себе возьмет,

Жена ты, лишь повинуйся, неверного дочь

Он муж, сам знает, сколько жен ему брать

Как животное, жена стоять,

смотреть должна, неверного дочь.

Азербайджанское общество отличалось от других народов своим историческим развитием, национальными обычаями и традициями, идущими из культурного наследия социальных отношений мужчин и женщин. Азербайджанская культура, развитая в условиях интеграции на пересечении различных цивилизаций и мировых религий, стала неотъемлемой частью как национальных, так и общечеловеческих ценностей. Происходящие в настоящее время из-за глобализации социальные политические и культурные процессы оказывают свое влияние и на гендерные отношения. В этом контексте сохранение и развитие национальных ценностей становится более актуальным.

Неравенство полов в различных обществах проявляется в различной форме. Изучая положение мужчин и женщин, можно определить культурные традиции общества, духовные качества народа, его мировоззрение. Неравенство полов в обществе для живущих в нем людей вовсе не всегда было проблемой. Естественно, что это связано с осознанием обществом существующей действительности. В Азербайджане эпоха просвещения также внесла свой вклад в проблему взаимоотношений полов (Nasraddinov, 2008: 14). Среди поднятых азербайджанскими просветителями основных проблем особое место занимают права человека, в том числе вопрос свободы женщин. Азербайджанские просветители, в отличие от западных, относились к вопросу бытия женщины очень прогрессивно. Проблему свободы женщины они выдвинули как основной фактор национального пробуждения. И АДР, обеспечив участие женщин в выборах, стала одним из первых в истории человечества государств, предпринявших шаги к демократии и правам человека. Вопрос равенства мужчины и женщины в западной философской мысли теоретически поднимался социалистическими и марк- систскими учениями. Однако в работах Маркса дискриминация женщины рассматривалась как дискриминация человека в антагонистическом обществе в целом. Ф. Энгельс писал: «эволюция частной собственности и развитие классового устройства общества привели к всемирному историческому поражению женского пола» (Marks, 1953: 63).

В XX веке азербайджанские женщины приобрели равные с мужчинами права во всех сфеpax общественной, духовной, экономической жизни. Азербайджанская Республика 18 октября 1991-го года приняла Конституционный акт о государственной независимости и, вместе с тем, приняв всеобщую декларацию прав человека, заключительный акт Хельсинкского совета по правам человека, другие международные правовые акты, присоединилась к примерно 200 международным пактам, конвенциям и хартиям. Женщины Азербайджана наравне с мужчинами активно участвовали в социальных, политических процессах, производственной сфере, культуре и других свойственных человеку областях, и в качестве социальной группы, выделяющейся своими специфическими, демографическими характеристиками, повлияла на ход истории, сыграла и продолжает играть значительную роль в определении развития общества.

Положение женщины в каждой нации является мерилом культурной ценности нации. Одним из новых гуманистических направлений, возникших в середине XX века, является гендерное направление. В качестве мировоззрения в контексте социально-культурных отношений и положения женщины и мужчины началась с формирования раннего человеческого общества. Естественно, что общество состоит из двух отличающихся друг от друга полов. Взгляды об отношениях между этими отличающимися друг от друга полами распространились, можно сказать, на все аспекты культуры и науки. Одним из подобных областей является азербайджанская литература.

Общеизвестно, что культура впервые возникла на Востоке, а затем постепенно интегрировалась на Запад. Древний Восток, в свою очередь, подарил мировой истории многочисленных философов, литераторов, государственных деятелей и мыслителей. В работах каждого писателя и поэта можно встретить актуальные проблемы эпохи, в которых они живут. Некоторые из этих проблем остаются актуальными и в настоящее время. Одной из подобных проблем является отношение к женщине. 
Следует отметить, что гендерная концепция не основывается на философии «побежденный мужчина - победившая женщина». Это выражает конкретно отношение важного к существующему. Для ясного выражения этой идеи необходимо рассмотреть данную проблему в религиозных, моральных, философских и литературных текстах. Во многих сурах Корана, являющегося воплощением милости нашего Всемогущего Бога к человеческому роду, мы видим, что отношение к женщине столь же прекрасно, как к матери, рождающей на свет ребенка. Это важно. Интересно, женщина во все времена удостаивается подобного отношения? Ответ прост - если даже сегодня вопросы свободы женщин, женского равноправия и пр. все еще на повестке, следовательно, решение данной проблемы сохраняет свою актуальность. Правда, по истечению времени, на передний план выдвигается какая-либо сторона данной проблемы. Однако во всех случаях женская проблема находится в центре внимания. Таким образом, из анализа творчества азербайджанского писателя Юсифа Везир Чеменземинли можно сделать вывод о том, что женщины должны морально совершенствоваться, быть достойны почитаемому в исламе и в обществе имени и принадлежности к матери (Chemenzeminli, 1976: 100). Женщина - мать, на которую возложена столь большая ответственность, должна знать свою собственную ценность и осознавать эту ответственность. Потому что наказание за духовную жажду матерей несут и дети в семье, и общество.

В XIX веке видные азербайджанские писатели Дж.Мамедкулизаде, М.Ф. Ахундов, Ю.В. Чеменземинли коснулись в своих произведениях бесправия женщин и корни этого бесправия видели именно в просвещении. Как в философских произведениях, так и в пьесах одного из них, М. Ахундова, в очень широком аспекте рассматривается положение женщин в XIX веке, их образ жизни. Они подробно передают образ мышления, мировоззрение азербайджанской женщины в своих произведениях.

\section{Результаты и обсуждение}

Говоря словами Дж. Мамедкулизаде, М.Ф. Ахундов вывел на сцену восточную женщину. Там, благодаря ему, она говорила, смеялась, плакала, и там впервые появилась среди мужчин.

А. Ахвердиев, выражая эти взгляды иначе, писал, что создание женских образов в то время было большой революцией в литературе. В пьесах Ахундова женщины умнее, проницательнее и вдумчивее мужчин. Впервые М.Ф. Ахундов сказал, что женщина в обществе должна обладать и моральным правом, и равными с мужчинами правами. Ахундов из существовавших в тот период государственных устройств отдавал предпочтение конституционному парламенту и полагал, что первой основой парламента является равенство прав. То есть, наряду с мужчинами, равные права должны быть даны женщинам. Таким образом, М.Ф. Ахундов критиковал осуждение на невежество девушек и женщин неграмотными муллами, использовавшими правила шариата в своих собственных интересах. Изобразив и в своих философских произведениях, и в пьесах бесправие азербайджанской женщины, разоблачил жестокие беды, случившиеся с ними именно из-за этого бесправия. Он писал, что женский род в правилах свободы должен быть приравнен с мужским родом «во всех правах человека». «Европейские философы считали женщин равными мужчинам во всех правах человека и свободы. Сегодня даже в некоторых странах континента женщины вовлечены в дела по управлению государством» (Akhundov, 1976:137). Таким способом значительно продвинувшийся, благодаря своему мировоззрению, Ахундов считал, что азербайджанские женщины могут и должны занимать более высокое место в обществе. В своих работах Ахундов, уделявший больше внимания образам женщин, плохое положение, в которой оказались женщины, именно на их языке связывал именно с их бесправием. Вместе с тем, он осуждал мужчин, которые использовали бесправие женщин для их превращения в объект «торговли». В пьесе «Hekayati-xırs quldurbasan» («Медведь - победитель разбойника») устами Перизад, показав женское бесправие, указал на наличие прав на них у отца и дяди. Отец или дяди выдают девушек за кого-то замуж лишь ради своих собственных интересов, и девушки спокойно подчиняются этому.

Азербайджанский философ порицал многоженство и говорил, что многоженство «является откровенным гнетом в отношении слабого пола». Например, он в своем произведении «Sərgüzəşti-xani-Lənkəran» («Приключения визиря Ленкоранского ханства») устами женских персонажей показал, к каким трагедиям приводит многоженство.

\section{Заключение}

Таким образом, мы видим, что азербайджанские поэты и писатели большое место в своих произведениях уделяли описанию образа азербайд- 
жанской женщины, ее роли в обществе. Многие авторы отмечали, что азербайджанская женщина более волевая, более духовно богатая и она сильнее мужчины. Но в то же время многие авторы отмечали, что в обществе нет равных прав между мужчинами и женщинами, что у многих женщин вообще отсутствуют такие права. На женщину общество, как и мужчина в целом, смотрит как на «недалекое существо», которое должно ухаживать и присматривать за детьми, готовить пищу, мыть посуду, стирать одежду. Поэтому в произ- ведениях М.А. Сабира, М.В. Ахундова красной нитью проходила мысль, что единственным путем избавления азербайджанской женщины от невежества является образование. Только образованная, имеющая профессию, сильная женщина может требовать разрешения гендерных проблем в обществе. И поэтому в XXI веке, в котором мы сейчас живем, наши девушки и женщины по причине отсутствия образования, а также в силу незнания своих прав, сталкиваются с подобными проблемами как в семье, так и в обществе.

\section{Литература}

Абдуллабекова Г. Просветительство в Азербайджане и Европе. - Баку: Наука, 2016. - 127 с.

Агвердиев А. Рассказы. - Баку: Азернешр, 1941. - 112 с.

Ализаде А. Женское мировосприятие и его художественная реализация в прозе современных русских и английских писательниц. - Баку: Мутарджим, 2017. - 160 с.

Ахундов М.Ф. Произведения. - Баку: Наука, 1976. - 234 с.

Бахшалиев А. Социально-психологическая сущность национально-нравственных ценностей Азербайджана. - Баку: Наука, 2011. - $78 \mathrm{c}$.

Везиров Н. Пьесы. - Баку: Издательство Детской литературы, 1951. - 81 с.

Гаджибеков У. Избранные произведения. - Баку: Наука, 1985. - 293 с.

Джафаров М. Дж. Мирза Алекбер Сабир. - Баку: Азернешр, 1962. - 33 с

Маркс К., Энгельс Ф. Избранные произведения. - Баку: Наука, 1953. - 456 с.

Марьенко И. Нравственное становление личности. - М.: Педагогика, 1985. - 101 с.

Насраддинов Н. Из истории просветительства // газета Проблемы образования. - 2008. - 11-20 декабря. - С. 14.

Проблемы социальной психологи личности. - Саратов: Саратовский Государственный Университет, 2008. - 345 с.

Сидги М. Т. Избранные произведения. - Баку: Гянджлик, 1969. - 125 с.

Фараджев С. Азербайджанская женщина в культурно-просветительской истории // Газета Культура. $-2011 .-13$ апреля. - С. 13

Чеменземинли Ю. В. Избранные произведения. - Баку: Гянджлик, 1976. - 141 с.

\section{References}

Abdullabekova G. (2016) Prosvetitelstvo v Azerbaijane i Yevrope [Education in Azerbaijan and Europe]. Baku: Nauka, 127 p. (In Russian).

Hagverdiyev A. (1941) Rasskazi [The stories]. Baku: Azerneshr, 112 p. (In Azerbaijani).

Alizade A. (2017) Jenskoye mirovospriyatiye i ego hodojestvennaya realizasiya v proze sovremennih russkih I angliyskih pisatelnits [Women's perception of the world and its artistic realization in the prose of contemporary Russian and English writers]. Baku: Mutarjim, 160 p. (In Russian).

Akhundov M. F. (1976) Proizvedeniya [Works]. Baku: Nauka, 234 p. (In Azerbaijani).

Bakshaliyev A. (2011) Sosialno - psihologicheskaya sushnost nasionalno-nravstvennih sennostey Azerbaijana [Sociopsychological essence of the national-moral values of Azerbaijan]. Baku: Nauka. 78 p. (In Azerbaijani).

Vezirov N. (1951) Pyesi [Plays]. Baku: Izdatelstvo Detskoy literaturi. 81 p. (In Azerbaijani).

Hajibekov U. (1985) Izbranniye proizvedeniya [The selected works]. Baku: Nauka, 293 p. (In Russian).

Jafarov M. J. (1962) Mirza Alekper Sabir [Mirza Alekper Sabir]. Baku: Azerneshr, 33 p. (In Russian).

Marks K. (1953) Engels F. Izbranniye proizvedeniya [The selected works]. Baku: Nauka, 456 p. (In Azerbaijani).

Maryenko I. (1985) Nravstvenniye stanovleniye lichnosti [Moral formation of personality]. Moscow: Pedagogika, 101 p. (In Russian).

Nasraddinov N. (2008). Iz istorii prosvetotelstva [From the history of enlightenment]//gazeta Problemi obrazovaniya, 11-20 dekabrya, p.14 (In Azerbaijani).

Problemi (2008) sosialnoy pxihologii lichnosti [Problems of social psychologists of personality]. Saratov: Saratov State University, 345 p. (In Russian).

Sidgi M. T. (1969). Izbanniye proizvedeniya [The selected works]. Baku: Ganclik, 125 p. (In Azerbaijani)

Farajev S. (2011). Azerbaijanskaya jenshina v kulturno-prosvetitelskoy istorii [Azerbaijani woman in cultural and educational history]// gazeta Kultura. 13 aprelya. p.13. (In Azerbaijani).

Chemenzeminli Y. V. (1976). Izbranniye proizvedeniya [The selected works]. Baku: Ganjlik, 141 p. (In Azerbaijani). 